Relations industrielles

Industrial Relations

\title{
A Life in Balance? Reopening the Family-Work Debate, edited by Catherine Krull and Justyna Sempruch, Vancouver, B.C.: UBC Press, 2011, 280 pp., ISBN: 978-0-7748-1968-8.
}

\section{Carolyn Troup}

Volume 68, numéro 3, été 2013

URI : https://id.erudit.org/iderudit/1018442ar

DOI : https://doi.org/10.7202/1018442ar

Aller au sommaire du numéro

\section{Éditeur(s)}

Département des relations industrielles de l’Université Laval

\section{ISSN}

0034-379X (imprimé)

1703-8138 (numérique)

Découvrir la revue

Citer ce compte rendu

Troup, C. (2013). Compte rendu de [A Life in Balance? Reopening the Family-Work Debate, edited by Catherine Krull and Justyna Sempruch,

Vancouver, B.C.: UBC Press, 2011, 280 pp., ISBN: 978-0-7748-1968-8.] Relations industrielles / Industrial Relations, 68(3), 537-539.

https://doi.org/10.7202/1018442ar

Tous droits réservés @ Département des relations industrielles de l’Université Laval, 2013
Ce document est protégé par la loi sur le droit d'auteur. L'utilisation des services d'Érudit (y compris la reproduction) est assujettie à sa politique d'utilisation que vous pouvez consulter en ligne.

https://apropos.erudit.org/fr/usagers/politique-dutilisation/ 
théories mises de l'avant, provenant aussi bien de la psychologie environnementale, d'une dynamique identitaire de genre ou encore de la remise en cause du modèle de l'emprise par l'analyse, pour ne citer que quelques exemples, constituent une qualité indéniable de ce collectif. Sur le plan méthodologique, le recours à des questionnaires et à des entretiens, bien que les échantillons soient souvent restreints, ainsi que les études ethnographique ou longitudinale effectuées dans des organisations variées représentent également une force de cet ouvrage.

Les forces constituent aussi les principales limites de ce collectif. Si la cohérence d'ensemble de ce collectif est bien rendue par la prise en compte du seul champ disciplinaire de la psychologie du travail et de l'ergonomie, annoncée d'emblée dès la préface de l'ouvrage, l'ajout d'autres contributions plus sociologiques aurait certainement enrichi notre compréhension des identités, des compétences et des pratiques professionnelles. Au-delà de l'individu, la sociologie du travail aurait, à notre avis, permis d'approfondir la réflexion sur les identités collectives, à peine effleurées. De plus, si certains chapitres couvrent des recherches réalisées dans divers pays européens, la plupart des études proviennent de cas français.

Somme toute, et même si un certain manque de profondeur de l'analyse et des discussions est parfois à déplorer, la structure exemplaire des chapitres, plutôt courts, facilite la lecture de ces thèmes complexes pour les étudiants et les praticiens. Les chercheurs pourront aussi y trouver leur compte puisque le caractère novateur de plusieurs outils et modèles conceptuels inspirera, nous l'espérons, les études futures sur le développement des identités professionnelles et des compétences.

\section{Catherine Le Capitaine}

Université Laval

\section{A Life in Balance? Reopening the Family-Work Debate}

edited by Catherine Krull and Justyna Sempruch, Vancouver, B.C.: UBC Press, 2011, 280 pp., ISBN: 978-0-7748-1968-8.

As we advance into the $21^{\text {st }}$ century the debate on work and family has not dwindled and neither has the number of books on the subject. Although each contributes a unique social-political perspective, there is a striking similarity across these books on the nature of industrialized nations and society today. A Life in Balance voices a Canadian perspective whose aim is to reshape the debate in the literature that investigates how people integrate work and care responsibilities in their daily living. The book is organized into three main sections and takes a feminist perspective to break down the core issues which centre around the assumed incompatibility and artificial division between work and family. Its intention is to move current debates that centre around conflict and reconciliation towards a discussion of the interdependence of paid work and family utilizing a model that is based on the diversity of care needs and caregivers. Although this book is situated in the Canadian context and draws from Canadian specialists and social contexts, it has relevance for other industrialized countries with different policy and social contexts.

The first section starts by breaking down entrenched myths with a chapter by Krull and, as its title suggests, it destabilizes the myth of the nuclear family by illustrating Canadian trends of family life that are far from the "male breadwinner family." It focuses on a topic that is relevant to most industrial countries where substantial changes have occurred since the 1950s, such as the decline in marriage, increase in divorce rates, diversification of family structure and increased women's labour force participation. This is reinforced by the chapter by Mandell and Wilson on care 
work that examines the gendered and class dynamics of intergenerational care work. Here the authors emphasize both the invisibility of care work and how the idealized norms of caring are maintained and reinforced.

The second section investigates the integration of work and family from a range of perspectives that reinforce the diversity of family life and the real challenges that occur for some members of the community. Of particular note is the positive view that integration has in the chapters by Baines and Freeman, which illustrates the indigenous meanings of care and how healing can grow out of this. This context has been undertaken by few, if any, as so much attention is given to middle class struggles. This could provide an interesting comparative national study with scholars interested in indigenous issues of work and family. The chapter by Eichler highlights the learning opportunities that arise in the context of care. Furthermore, the chapter by Doucet presents her results of a study on fathering in the community, which is an important aspect that must be given greater emphasis if it is to moving this debate away from being a women's issue and the role of fathering is to be given greater importance. While there has been more attention towards fathering, especially among Swedish scholars, this book emphasizes the role of community and the changes that need to occur to illuminate the obstacles that men face when they attempt to participate more equitably in family life responsibilities.

Throughout the book several chapters are devoted to the discussion of policy and they illustrate how public policy shapes and reinforces gendered employment patterns and parenting. The chapter by Baker focuses on liberal welfare states and presents comparisons with US, UK, Australia and New Zealand models of support for child care, presenting a historical comparison that would be of use to students and scholars who come to this topic of research from outside the political and policy areas. The chapter by Daniels challenges the myth that people make choices to work and to have a family, arguing that there is a lack of attention to care work as it "intermingles" with market work and pointing out that citizenship rights have been eclipsed by market citizenship. The themes of social citizenship and social provisioning highlight the myth of choice that neoliberal policy has come to embody while it furthers the undervaluing of care. The chapter by Albanese illustrates the positive change that has occurred in Quebec's policy relating to child care, illustrating the lessons that can be learned.

The third section focuses on feminist informed initiatives. The chapter by Sempruch takes a social construction perspective on care, highlighting the feminine-care and masculine-economic "scripts," as she calls them, and how they get played out, maintained and reinforced. The chapter by Fudge examines the concept of time pressure, illustrating how the work-life divide is maintained, creating what is commonly referred to as the "second shift" for women and maintaining the existence of the gendered institution. There is discussion on issues associated with gender-neutrality and on gender mainstreaming policies where Canada has been an international leader (Hankivsky, 2008), with a discussion on its mixed outcomes and criticism by many feminist scholars that offer researchers ideas on future research and the need for further evaluation to be undertaken.

A Life in Balance has a number of noteworthy strengths to encourage scholars and policy makers alike to focus on the challenges associated with breaking down gendered stereotypes that extend across class, race and ethnicity and centre on care in society. It places care within a broader socio-political context outside of the traditional private sphere. Its strength lies in its call to researchers to take a "culturally 
integrative and cross-sectional positioning" to develop the work-life debate further. Throughout the book, the significance of the connection between care and femininity and how feminine norms are maintained and have become entrenched is emphasized. But it is also balanced with the importance of examining masculine norms. This book would be of particular value to students, scholars and practitioners who may come to this topic from outside of sociology as a means to understand the impact of policy and gendered norms associated with work and care and how this reinforces gendered patterns of work and family life. It challenges gender assumptions that continue to be neglected in the applied research literature on this topic, where work-life initiatives are too often seen as "women's issues."

\section{Carolyn Troup}

Griffith University

\section{Gouverner les fins de carrière à distance. Outplacement et vieillissement actif en emploi}

par Thibauld Moulaert, Bruxelles : P.I.E. Peter Lang, 2012, 287 p., ISBN : 978-905201-873-7.

Le livre de Thibauld Moulaert présente une approche de la gouvernance des fins de carrière qui consiste à jouer sur les incitations des individus à se replacer sur le marché du travail. Notons d'emblée la très grande richesse des sources théoriques auxquelles réfère l'auteur tout au long de l'ouvrage et qu'il tente d'appliquer à la problématique du maintien en emploi des séniors, à travers notamment le cas de la Belgique. L'ouvrage s'articule autour de deux parties traitant de la gouvernance des fins de carrière comme enjeu social (première partie) et comme problématique sociologique (deuxième partie).

Dans son introduction, I'auteur explicite la question de recherche, s'agissant de mettre en exergue l'émergence de pratiques d'accompagnement des travailleurs plus âgés à partir de l'exemple belge de l'outplacement. L'outplacement peut être défini comme le fait qu'un travailleur tente de retrouver lui-même un emploi ou de développer une activité professionnelle en tant qu'indépendant, et ce, par le biais de I'action publique qui fait appel à des consultants. En d'autres termes, I'outplacement représente une forme de sécurisation des parcours professionnels des individus qui ne se voient plus sortir du marché du travail pour devenir inactifs. II s'agit là d'une stratégie gouvernementale qui consiste à offrir, aux 45 ans et plus, une aide à retrouver un emploi, et ce, par le biais d'un service de placement privé, stratégie susceptible de s'avérer plus rentable que de payer des indemnités de chômage, le but ultime visé étant d'améliorer le taux d'emploi des travailleurs. Dans cette optique, I'outplacement est un outil pour l'action publique dans le cadre d'une politique pour le vieillissement actif. II faut toutefois préciser que le droit à l'outplacement devient aussi une obligation dans la mesure où l'individu qui le refuse verra ses allocations de chômage suspendues, et ce, pour une durée pouvant atteindre 52 semaines.

Dans une première partie intitulée Gouverner les fins de carrière : un enjeu social, composée de trois chapitres, l'auteur souligne l'importance, dans un contexte de vieillissement de la population et des risques de pénuries de main-d'œuvre, de susciter un " vieillissement actif » qui va au-delà d'une prolongation de carrière pour ne pas laisser se retirer de manière anticipée des travailleurs du marché de l'emploi et qui est assimilable à une véritable gestion des fins de carrière. Le mode de gouvernance des fins de carrière constitue un véritable enjeu sociologique dans la mesure où l'on considère le travail des consultants comme intégré au processus général de l'action de l'État. Par gouvernance, il faut entendre un exercice du pouvoir de l'État sur la population qui ne se définit pas comme un mode d'action agissant directement sur les indi- 